\title{
Autologous adipose-derived stromal cell treatment for patients with refractory angina (MyStromalCell Trial): 3-years follow-up results
}

\author{
Abbas Ali Qayyum ${ }^{1 *} \mathbb{D}$, Anders Bruun Mathiasen ${ }^{1}$, Steffen Helqvist ${ }^{1}$, Erik Jørgensen², \\ Mandana Haack-Sørensen ${ }^{3}$, Annette Ekblond ${ }^{3}$ and Jens Kastrup ${ }^{1,3}$
}

\begin{abstract}
Background: Stem cell therapy is investigated as a treatment option for patients with ischemic heart disease. In this study, long-term safety and efficacy of autologous intra-myocardial injections of adipose-derived stromal cells (ASCs) was studied in patients with refractory angina.

Methods: Sixty patients with coronary artery stenosis and preserved left ventricular ejection fraction were 2:1 randomised to intramyocardial injections of ASCs or saline and followed for 3 years.

Results: For patients in the ASC group, the bicycle exercise time and the exercise performance in watt were unchanged ( $383 \pm 30 \mathrm{~s}$ to $370 \pm 44 \mathrm{~s}, \mathrm{P}=0.052$ and $81 \pm 6$ to $78 \pm 10, \mathrm{P}=0.123$, respectively), but the performance in METs was reduced significantly ( $4.2 \pm 0.3$ to $4.0 \pm 0.4, P=0.027$ ) during the follow-up period. However, in the same period, there was in the placebo group a significant decline in bicycle exercise time (437 $\pm 53 \mathrm{~s}$ to $383 \pm 58 \mathrm{~s}$, $P=0.001)$, the exercise performance measured in watt $(87 \pm 12 \mathrm{~W}$ to $80 \pm 12 \mathrm{~W}, \mathrm{P}=0.019)$ and in METs $(4.5 \pm 0.4$ to $4.1 \pm 0.4, P=0.002)$. Moreover, angina measured as CCS class was significantly reduced in the ASC group but not in the placebo group ( $2.5 \pm 0.9$ to $1.8 \pm 1.2, P=0.002$ and $2.5 \pm 0.8$ to $2.1 \pm 1.3, P=0.186$, respectively). However, no significant change was observed between the two groups.
\end{abstract}

Conclusions: Patients receiving ASCs had improved cardiac symptoms and unchanged exercise capacity, in opposition to deterioration in the placebo group.

Trial registration ClinicalTrials.gov Identifier: NCT01449032. Registered 7 October 2011—Retrospectively registered, https:// www.clinicaltrials.gov/ct2/show/NCT01449032?term=jens+kastrup\&rank=7

Keywords: Adipose derived stromal cells, Chronic ischemic heart disease, Regeneration, Stem cell therapy, Refractory angina

\section{Background}

One of the leading reasons for death worldwide is related to ischemic heart disease [1]. Improvements in medical and interventional therapies have made the disease a chronic illness for a lot of patients [2]. Even though, the patients are not suffering from cardiac symptoms, the

\footnotetext{
*Correspondence: abbas.ali.qayyum@regionh.dk

1 Department of Cardiology \& Cardiac Catheterization Laboratory 2014, Rigshospitalet University of Copenhagen, Inge Lehmanns Vej 7 , 2100 Copenhagen, Denmark

Full list of author information is available at the end of the article
}

disease is in progress and it is a matter of time before patients develop cardiac symptoms and cardiac events. Atherosclerosis in coronary arteries initially results in asymptomatic left ventricle dysfunction, which reduces cardiac output leading to left ventricle overload and dilatation, and over time it leads to symptomatic left ventricular dysfunction due to ischemia, apoptosis or necrosis. The symptoms related to ischemic myocardium can be reduced using anti-anginal medical or invasive therapies but the underlying disease does not disappear. Stem cell therapy can potentially regenerate ischemic myocardium and is investigated for that purpose in clinical trials. One 
of the promising cell sources is adipose-derived stromal cells (ASCs), which can be obtained easily from adipose tissue on the abdomen and is comparable to the bone marrow derived mesenchymal stromal cells (MSCs) [3-7].

Previously, a few studies have used autologous adipose derived cells for patients with ischemic heart disease, but these cells were freshly harvested non-culture expanded cells [8-10]. Thus, a limited non-homogenous cell population was given to each patient. Ex vivo culture expansion of ASCs gives the opportunity to deliver a more homogenous and a larger amount of autologous cells to each patient. The anti-apoptotic effect and angiogenesis mediated by ASCs have preclinical been suggested to be related to cytokines such as IGF-I and VEGF $[11,12]$. In a porcine model of acute myocardial infarction, intracoronary administration of freshly harvested ASCs showed a significant reduced size of myocardial perfusion defect compared to the control group [13].

We assessed the safety and efficacy of intra-myocardial delivered vascular endothelial growth factor (VEGF$\mathrm{A}_{165}$ ) stimulated culture expanded ASCs in patients with chronic ischemic heart disease (CIHD) and refractory angina in a double-blinded placebo-controlled clinical study (MyStromalCell trial) [14]. After 6 months, ASC treatment was considered safe and the primary endpoint bicycle exercise capacity increased significantly in the ASC treated group which was not the case for patients who received intramyocardial injections of saline [15].

With this, the final 3 years follow-up results from MyStromalCell trial will be presented. These results are the first long-term data on intramyocardial delivered ASCs in patients with CIHD and refractory angina.

\section{Methods}

\section{Study overview}

MyStromalCell trial is a single-center phase II, doubleblinded, placebo-controlled study investigating the safety and efficacy of intra-myocardial injections of autologous ASCs in patients with CIHD and refractory angina.

The study protocol was approved by the Danish National Ethical Committee (02-268856) and Danish Medicines Agency (2612-2867), and complied with the Declaration of Helsinki. The study is registered in ClinicalTrials.gov (NCT01449032). The Good Clinical Practice Unit of the Capital Region, Denmark monitored the trial throughout the 3 years study period. All patients received oral and written information about the study and signed a written informed consent prior to inclusion.

\section{Patient population}

In total, 60 patients were enrolled aged $30-80$ years old with left ventricular ejection fraction (LVEF) $>40 \%$ and $\geq 1$ significantly coronary artery stenosis not amenable for revascularization. The decision was made by the Heart team, which consisted of study unrelated persons. Despite optimal anti-anginal therapy, the patients had significant heart symptoms.

Inclusion and exclusion criteria are described in Table 1. The patients were randomized 2:1 to ASC or saline injections.

After intramyocardial delivery of saline or ASCs, the patients were followed 1, 3, 6, 12, 24 and 36 months after the injections (Fig. 1).

\section{Cell preparation and culturing}

In local anesthesia, approximately $100 \mathrm{ml}$ of subcutaneous adipose tissue was obtained from the abdomen of each patient. Isolation and expansion of ASCs has been published previously [14, 15]. Briefly, the lipo-aspirate was washed with phosphate-buffered saline and the adipose tissue was digested by collagenase NB6, neutralized with complete medium containing Dulbecco's Modified Eagle's Medium low glucose $1 \mathrm{~g} / \mathrm{l}, 1 \%$ Penicillin/Streptomycin $(10,000 \mathrm{U} / \mathrm{ml}$ and $10.000 \mu \mathrm{g} / \mathrm{ml}$, respectively) and 10\% Fetal Bovine Serum (FBS). Then the suspension was filtered, centrifuged, and re-suspended in complete medium [16]. The isolated stromal vascular fraction was seeded in $75 \mathrm{~T}$ culture flasks. Every 3-4 days, the complete medium was changed, and the culture was passaged at $80-90 \%$ confluence. The ASCs were cultured in serum reduced VEGF- $\mathrm{A}_{165}$ medium for 7 days prior to the intramyocardial injections. Each patient was treated with the total amount of cells reached after 2 passages.

\section{Electromechanical mapping and intramyocardial injection of ASCs}

A 3D electromechanical map of left ventricle was created using NOGA ${ }^{\circledR}$ system (Biologics Delivery Systems, CA, US). An 8-french NOGA Myostar ${ }^{\circledR}$ injection catheter was used to deliver 10-15 injections of $0.2 \mathrm{ml}$ of ASCs or saline into the ischemic region of the left ventricle.

\section{Endpoints}

Along with clinical examination, registration of side effects, the patients performed bicycle exercise test at baseline, 3, 6, 12, 24 and 36 months after injections. The efficacy endpoints included changes in Canadian Cardiovascular Society (CCS) and New York Heart Association (NYHA) classification, Seattle Angina Questionnaire, weekly use of nitroglycerin and weekly frequency of angina attacks. Moreover, 1 month after ASC/saline injections, the patients were clinically examined without performing bicycle exercise test. 


\section{Table 1 Inclusion and exclusion criteria}

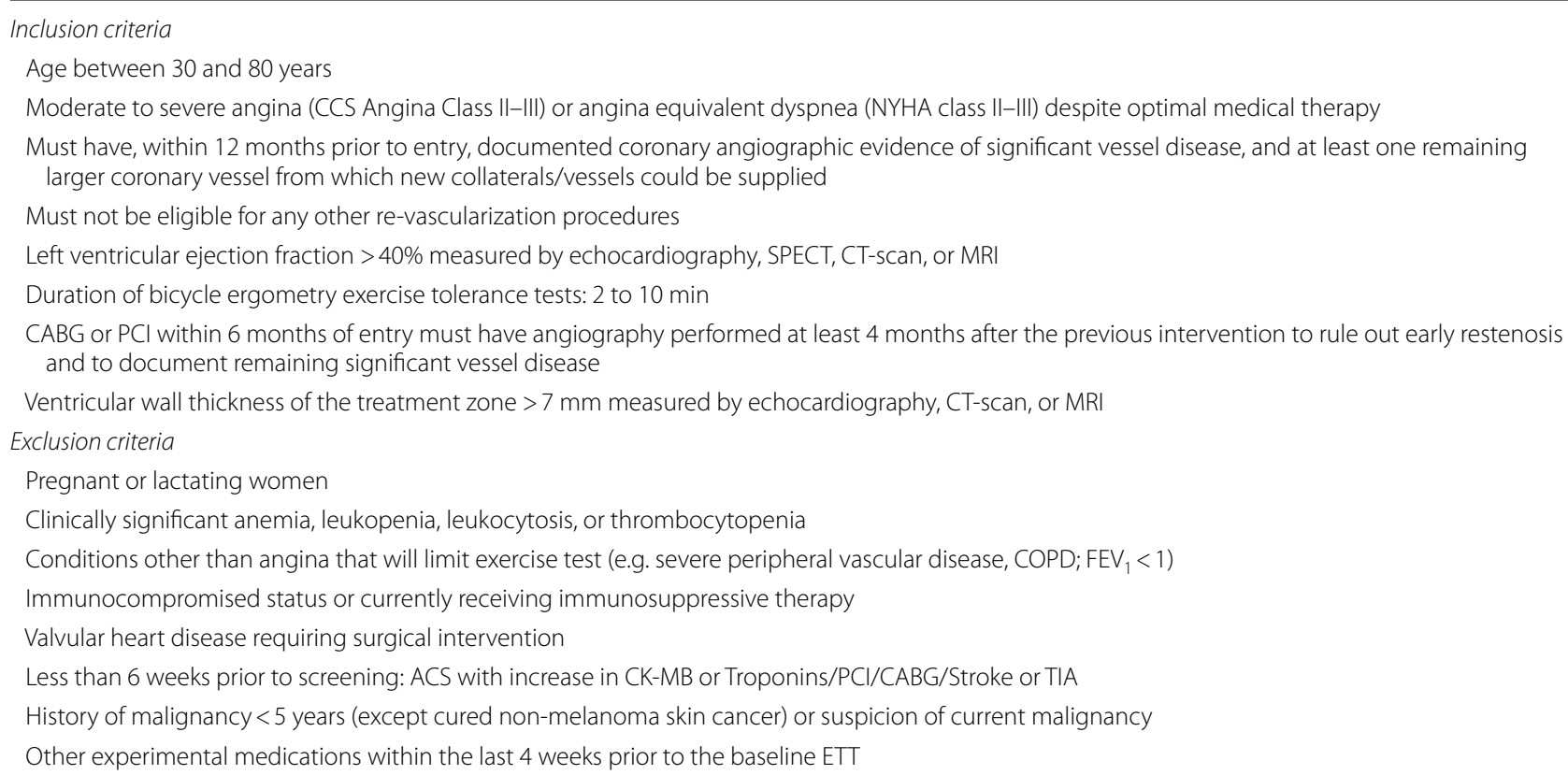

CABG coronary artery bypass grafting, CCS Canadian Cardiovascular Society, CT computed tomography, MRI magnetic resonance imaging, NYHA New York Heart Association, $P C I$ percutaneous coronary intervention, SPECT single-photon emission computed tomography, $A C S$ acute coronary syndrome, COPD chronic obstructive pulmonary disease, ETT exercise tolerance test, $F E V_{1}$ forced expiratory volume in $1 \mathrm{~s}, T I A$ transient ischemic attack

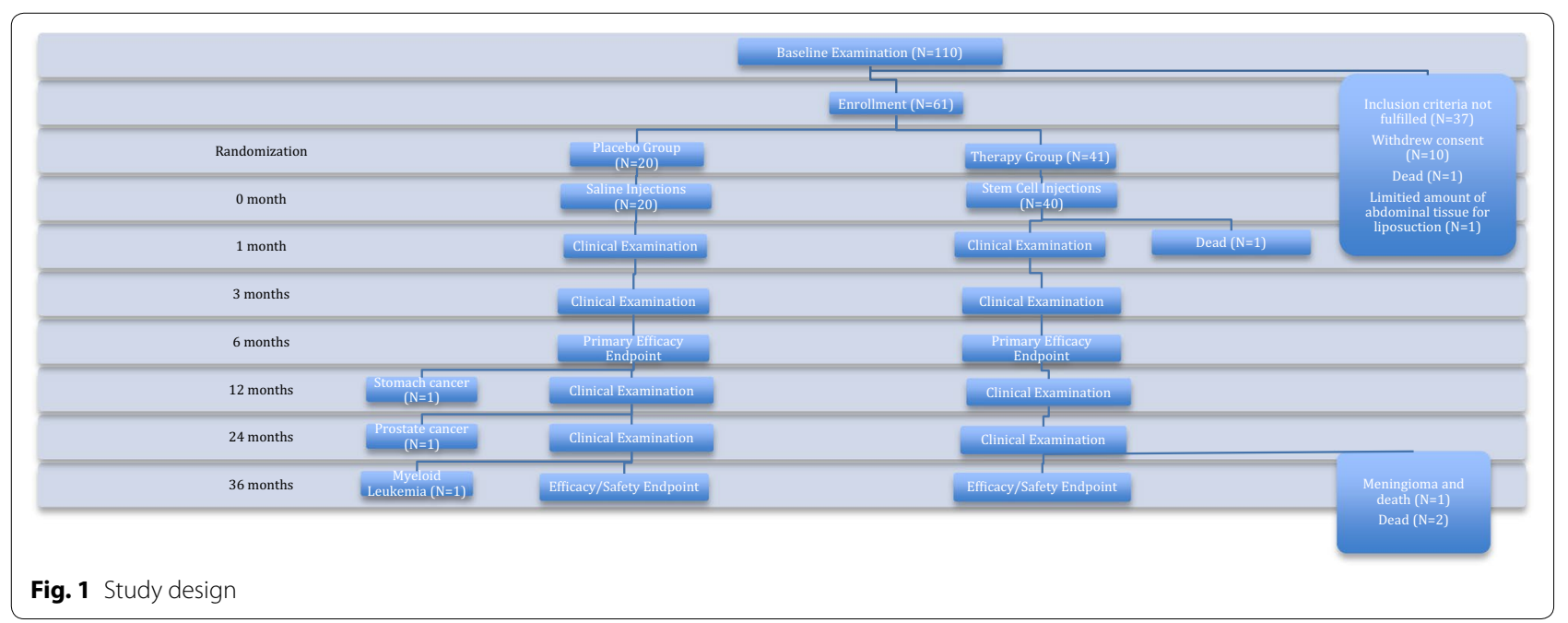

\section{Statistical analysis}

All statistical analysis was performed using SPSS version 23.0 (SPSS Inc., Chicago, Illinois). Continuous variables are presented as mean \pm standard deviation (SD) or $95 \%$ confidence interval and categorical variables are presented as numbers and percentages. Paired $t$-test is used for comparison of continuous data within groups while unpaired $t$-test is used for comparison between groups. Repeated measure with autoregressive covariance structure is used for follow-up data with more than two time-points (bicycle exercise data, symptoms, angina attacks, use of short-term nitroglycerin and Seattle Angina Questionnaire). The data were analyzed as intention-to-treat analysis with missing data filled in with last observation carried forward. Categorical data were compared using Fisher's exact or Chi-square test. A two-sided P-value of $<0.05$ was considered statistically significant. 
Table 2 Baseline characteristics

\begin{tabular}{llll}
\hline Parameter & Placebo $(\mathbf{n}=\mathbf{2 0})$ & ASC $(\mathbf{n}=\mathbf{4 0})$ & P-value \\
\hline Age (years) & $65.3 \pm 8.7$ & $65.5 \pm 9.7$ & 0.94 \\
Male gender & $20(100)$ & $35(87.5)$ & 0.02 \\
BMl (kg/m $\left.{ }^{2}\right)$ & $30.0 \pm 4.8$ & $30.0 \pm 4.1$ & 0.92 \\
Smoking & & & 0.19 \\
Current & $3(15)$ & $8(20)$ & \\
Previous & $16(80)$ & $23(57.5)$ & \\
Never & $1(5)$ & $9(22.5)$ & \\
Diabetes mellitus & $6(30)$ & $16(40)$ & 0.57 \\
Hypertension & $12(60)$ & $33(82.5)$ & 0.06 \\
Previous AMl & $10(50)$ & $26(65)$ & 0.26 \\
Previous CABG & $20(100)$ & $33(82.5)$ & 0.08 \\
Previous PCl & $15(75)$ & $28(70)$ & 0.69 \\
LVEF (\%) & $54 \pm 8$ & $52 \pm 8$ & 0.38 \\
\hline
\end{tabular}

$A M I$ acute myocardial infarction, $A S C$ adipose-derived stromal cell, $B M I$ body mass index, $C A B G$ coronary artery bypass grafting, $L V E F$ left ventricular ejection fraction, $n$ number of patients, $P C l$ percutaneous coronary intervention

Table 3 Baseline medication

\begin{tabular}{lcll}
\hline Medication & Placebo $(\mathbf{n}=\mathbf{2 0})$ & ASC $(\mathbf{n}=\mathbf{4 0})$ & P-value \\
\hline Acetylsalicylic acid & $19(95)$ & $35(87.5)$ & 0.65 \\
Clopidogrel & $7(35)$ & $11(27.5)$ & 0.56 \\
ACE-l or ARB & $13(65)$ & $29(72.5)$ & 0.42 \\
B-blocker & $16(80)$ & $33(82.5)$ & 1.00 \\
Calcium antagonist & $12(60)$ & $19(47.5)$ & 0.42 \\
Diuretics & $12(60)$ & $27(67.5)$ & 0.58 \\
Statins & $20(100)$ & $40(100)$ & 1.00 \\
Nitrate & $19(95)$ & $28(70)$ & 0.04 \\
Nicorandil & $6(30)$ & $5(12.5)$ & 0.16 \\
Ivabradine & $2(10)$ & $4(10)$ & 1.00 \\
\hline
\end{tabular}

$A C E-l$ angiotensin-converting enzyme inhibitor, $A R B$ angiotensin II receptor blockers, $A S C$ adipose-derived stromal cell, $n$ number of patients

\section{Results}

Forty patients were randomly allocated to the ASC group and treated with $72 \pm 45 \times 10^{6}$ ASCs culture expanded for $32 \pm 14$ days. The injection volume with the expanded ASCs was $3 \mathrm{ml}$. The cell viability was $89 \pm 5 \%$. No signs of contamination with bacteria, yeast or mycoplasma were detected. Remaining 20 patients received intramyocardial saline injections. Baseline characteristics and medicine are shown in Table 2 and 3, respectively.

\section{Safety}

During the 3 years follow-up, 4 patients died. Death of three patients was attributed to a cardiovascular event while 1 of the patient died due to meningioma. One patient died prior to 1-month examination, the other
Table 4 Serious adverse events during 3 years follow-up in the placebo and adipose-derived stromal cell (ASC) group

\begin{tabular}{lccc}
\hline Serious adverse events & Placebo $(\mathbf{n = 2 0 )}$ & ASC ( $\mathbf{n = 4 0 )}$ & P-value \\
\hline $\begin{array}{l}\text { Death } \\
\text { Hospitalizations }\end{array}$ & $0(0)$ & $4(10)$ & 0.291 \\
Myocardial infarction & $5(25)$ & $8(20)$ & 0.744 \\
Dyspnea & $0(0)$ & $1(2.5)$ & 1.000 \\
Anemia & $2(10)$ & $3(7.5)$ & 1.000 \\
Syncope & $1(5)$ & $0(0)$ & 0.333 \\
Peripheral edema & $0(0)$ & $1(2.5)$ & 1.000 \\
Angina worsening & $12(60)$ & $14(35)$ & 0.028 \\
Pneumonia & $1(5)$ & $4(10)$ & 0.656 \\
PCI & $7(35)$ & $6(15)$ & 0.101 \\
Heart failure & $0(0)$ & $4(10)$ & 0.291 \\
TIA/apoplexia cerebri & $2(10)$ & $0(0)$ & 0.107 \\
Pulmonary embolism & $0(0)$ & $1(5)$ & 1.000 \\
Cancer & $3(15)$ & $1(5)$ & 0.103 \\
\hline
\end{tabular}

Values are $\mathrm{n}(\%)$; $\mathrm{P}$ values are calculated using Fischer's exact test except for angina worsening, which is calculated using Chi-square test

$\mathrm{PCl}$ percutaneous coronary intervention, TIA transient ischemic attack

patients died 34, 35 and 36 months after treatment, respectively.

During follow-up time, 4 patients developed cancer. One patient from ASC group developed meningioma. The patients in the placebo group developed prostate cancer, stomach cancer and myeloid leukemia (Table 4).

Six patients did not show up for 36 months follow-up. Four of them were not alive, 1 had stomach cancer and was not able to show up and 1 patient had upper airway infection.

\section{Exercise tolerance testing}

At 3 years follow-up, the mean bicycle exercise tolerance time was un-changed in the ASC group from $383 \pm 30 \mathrm{~s}$ to $370 \pm 44 \mathrm{~s}(\mathrm{P}=0.052)$, while it decreased significantly in the placebo group from $437 \pm 53 \mathrm{~s}$ to $383 \pm 58$ s $(P=0.001)$ (Fig. 2). A significant decrease was also observed in the placebo group for the performance expressed in watt from $87 \pm 12 \mathrm{~W}$ at baseline to $80 \pm 12 \mathrm{~W}(\mathrm{P}=0.019)$, but was un-changed in patients treated with ASCs from baseline to 3 years follow-up $(81 \pm 6 \mathrm{~W}$ to $78 \pm 10 \mathrm{~W}, \mathrm{P}=0.123)$.

Corresponding metabolic equivalents (METs) was reduced significantly in both the ASC group (from $4.2 \pm 0.3$ to $4.0 \pm 0.4, \mathrm{P}=0.027)$ and in the placebo group (from $4.5 \pm 0.4$ to $4.1 \pm 0.4, \mathrm{P}=0.002$ ) during the 3 years follow-up period.

There were no significant differences between groups during the 3 years of follow-up (Table 5). 


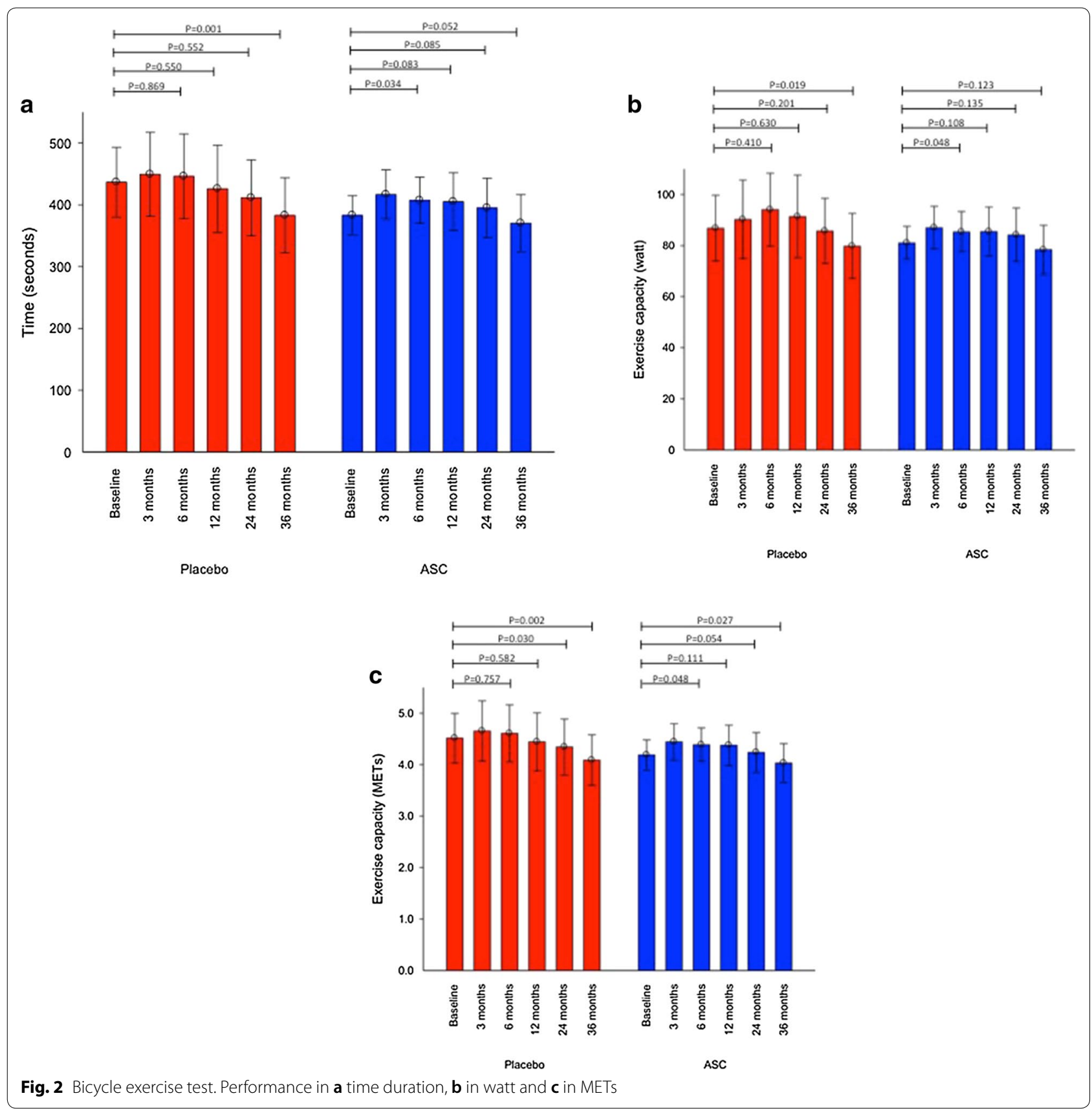

\section{Cardiac symptoms and anti-anginal medication}

During the 3 years follow-up period, significant decreased angina was observed measured as CCS classification in the ASC group ( $2.5 \pm 0.9$ to $1.8 \pm 1.2, \mathrm{P}=0.002)$ while the symptoms were unchanged the placebo group ( $2.5 \pm 0.8$ to $2.1 \pm 1.3, \mathrm{P}=0.186$ ) (Fig. 3).

The chest discomfort was significantly reduced in the placebo group during the period from baseline to 6 months follow-up but then increased again while the CCS classification was significantly reduced for patients in ASC group from baseline to 6 months follow-up and remained decreased during the entire follow-up period (Fig. 3).

For NYHA classification, there was a significant reduction observed in the ASC group $(2.4 \pm 0.6$ to $2.2 \pm 0.8, \mathrm{P}=0.007)$ while there was no significant change in the placebo group $(2.7 \pm 0.6$ to $2.4 \pm 0.8$, $\mathrm{P}=0.314$ ).

The patients reported significantly reduced number of weekly angina attacks in the ASC group $(\mathrm{P}=0.017)$ 
Table 5 Bicycle exercise test. Difference between groups

\begin{tabular}{|c|c|c|c|c|c|c|c|c|}
\hline & \multirow[t]{2}{*}{ Follow-up time } & \multirow[t]{2}{*}{ Group } & \multirow[t]{2}{*}{$\begin{array}{l}\text { Mean difference } \\
\text { from baseline }\end{array}$} & \multirow[t]{2}{*}{$\begin{array}{l}\text { Standard } \\
\text { deviation }\end{array}$} & \multirow[t]{2}{*}{$\begin{array}{l}\text { Mean difference } \\
\text { between groups }\end{array}$} & \multicolumn{2}{|c|}{$\begin{array}{l}95 \% \text { Confidence interval } \\
\text { of the difference }\end{array}$} & \multirow[t]{2}{*}{ P-value } \\
\hline & & & & & & Lower & Upper & \\
\hline \multirow[t]{6}{*}{ Time } & 12 months & Placebo & 10 & 118 & 34 & -29 & 97 & 0.288 \\
\hline & & ASC & -24 & 113 & & & & \\
\hline & 24 months & Placebo & 24 & 98 & 37 & -25 & 100 & 0.239 \\
\hline & & ASC & -13 & 121 & & & & \\
\hline & 36 months & Placebo & 51 & 100 & 39 & -13 & 91 & 0.141 \\
\hline & & ASC & 12 & 92 & & & & \\
\hline \multirow[t]{6}{*}{ Watt } & 12 months & Placebo & -4.4 & 24.2 & 0.4 & -12.3 & 13.1 & 0.952 \\
\hline & & ASC & -4.7 & 22.7 & & & & \\
\hline & 24 months & Placebo & 1.0 & 23.0 & 4.3 & -9.4 & 18.1 & 0.529 \\
\hline & & ASC & -3.3 & 25.9 & & & & \\
\hline & 36 months & Placebo & 6.6 & 23.4 & 4.0 & -7.5 & 15.5 & 0.488 \\
\hline & & ASC & 2.6 & 19.6 & & & & \\
\hline \multirow[t]{6}{*}{ Mets } & 12 months & Placebo & 0.07 & 1.00 & 0.28 & -0.23 & 0.78 & 0.277 \\
\hline & & ASC & -0.21 & 0.88 & & & & \\
\hline & 24 months & Placebo & 0.17 & 0.88 & 0.23 & -0.27 & 0.74 & 0.355 \\
\hline & & ASC & -0.07 & 0.93 & & & & \\
\hline & 36 months & Placebo & 0.41 & 0.86 & 0.27 & -0.16 & 0.69 & 0.212 \\
\hline & & ASC & 0.14 & 0.72 & & & & \\
\hline
\end{tabular}
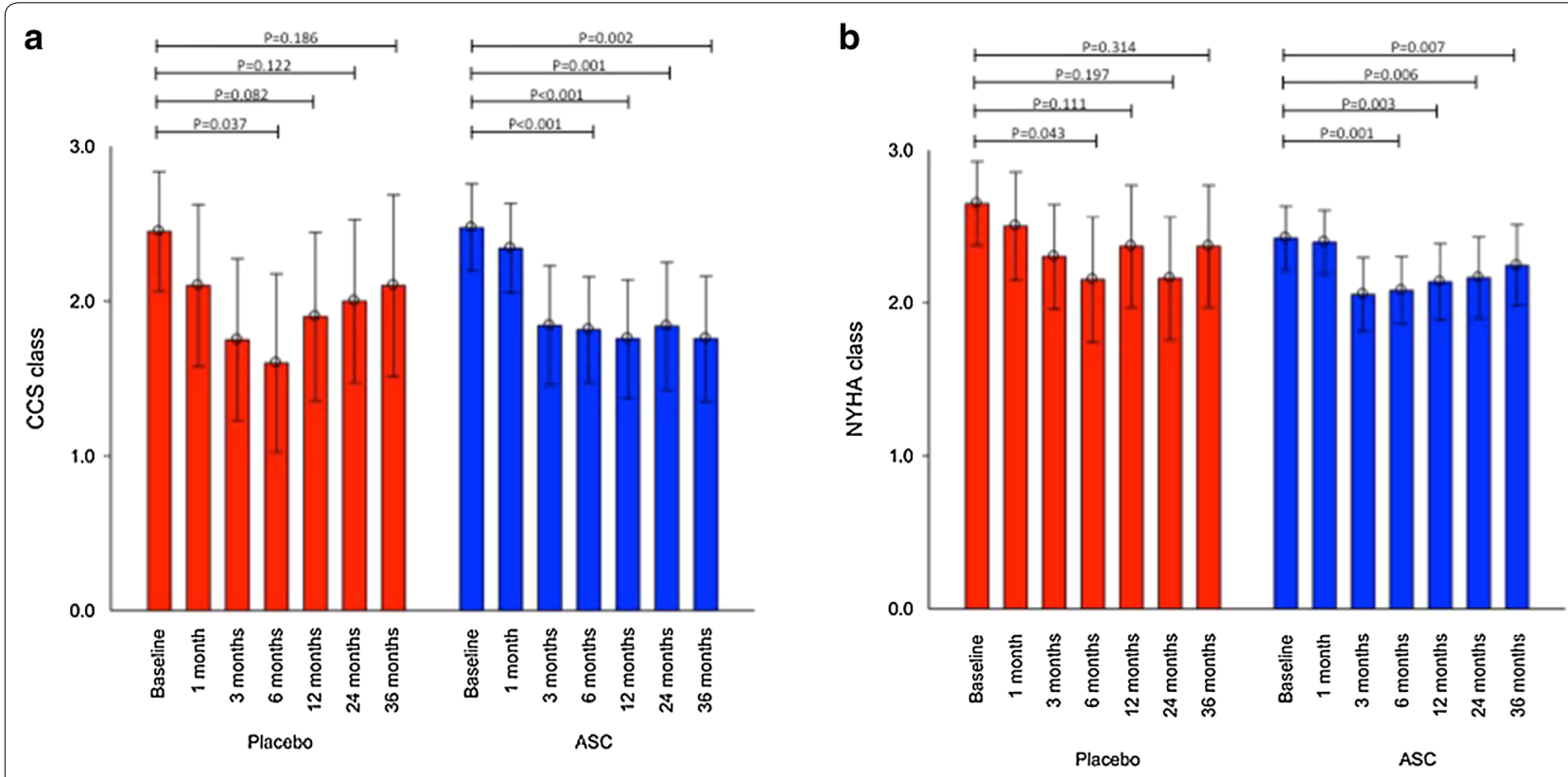

Fig. 3 Cardiac symptoms measured as a CCS classification and $\mathbf{b}$ NYHA classification

while this number was unchanged in the placebo group $(\mathrm{P}=0.425)$.

In the same period, the use of short-term nitroglycerin was unchanged in both groups (ASC: $\mathrm{P}=0.176$ and Placebo: $\mathrm{P}=0.123$ ).

\section{Seattle Angina Questionnaire}

Significant improved quality-of-life $\quad(\mathrm{P}<0.001$ and $\mathrm{P}=0.045$ for $\mathrm{ASC}$ and placebo group, respectively), angina stability $(\mathrm{P}<0.001$ and $\mathrm{P}=0.003$ for $\mathrm{ASC}$ and placebo group, respectively), angina frequency $(\mathrm{P}<0.001$ 
and $\mathrm{P}=0.012$ for ASC and placebo group, respectively) and physical limitation score $(\mathrm{P}=0.002$ and $\mathrm{P}=0.017$ for ASC and placebo group, respectively) was observed in both groups but no significant change in overall satisfaction score was seen in any of the groups $(P=0.489$ and $\mathrm{P}=0.604$ for ASC and placebo group, respectively). There were no differences in any parameter between the two groups.

\section{Discussion}

The present study is reporting long-term safety and efficacy data for the first in man randomized, double-blinded placebo-controlled study using VEGF- $\mathrm{A}_{165}$ stimulated culture expanded ASCs for patients with refractory angina.

The bicycle exercise performance decreased significantly in the placebo group but was unchanged in the ASC group except for the performance measured in METs at 3 years follow-up.

Cardiac symptoms measured as CCS class and the numbers of weekly angina attacks were significantly reduced during the 3 years of follow-up time for the patients treated with ASCs while there were no changes for the patients receiving saline injections. However, use of short-term nitroglycerin was un-changed in both groups.

For patients in both groups, significant improved quality-of-life, angina stability, angina frequency and physical limitation score was observed.

Chronic ischemic heart disease is a progressive disease. During the follow-up period of 3 years, 13 patients were admitted due to acute myocardial infarction and 26 due to angina worsening. The decrease in bicycle performance in the placebo group illustrates the progressive nature of coronary artery disease.

Interestingly, during the first 6 months follow-up period, significant improvement in heart symptoms of all patients was seen. However, the present long-term data demonstrated that patients allocated into the saline group returned to baseline cardiac symptoms but for patients in the ASC group, the heart symptoms remained decreased during the entire follow-up period. Along with this, the number of weekly angina attacks was only reduced in the ASC group. It can be speculated whether this effect over time in reduced cardiac symptoms would have been seen if only growth factors were injected. However, injection of growth factors may result in rapid dilution while ASCs are bigger in size and may stay in the injected tissue for a time period. Moreover, ASCs may secrete a cocktail of growth factors in a highly complex manner to promote angiogenesis. Nevertheless, for the patients it is highly important that any type of treatment results in decreased morbidity and mortality.
Previous published studies using exercise test as an outcome measure, show similar change in exercise capacity after $\mathrm{CD} 34^{+}$injections in patients with chronic ischemic heart disease and refractory angina [17-19]. In these studies, the patients received a standardized dose of cells. In the present study, the patients received the total amount of cells reached after two cell culture expansion passages and thus there were a patient-to-patient variation in the number of cells delivered.

Intra-myocardial injection of freshly harvested adiposederived cells have been used in patients with refractory angina, which showed that exercise capacity measured as METs in the cell group remained stable while there was a decrease in METs in the placebo group [9]. It is the same tendency as in our study.

Another study also using freshly harvested autologous adipose derived cells injected intramyocardially in patients with ischemic heart failure showed increased maximum oxygen consumption on exercise treadmill in patients receiving cells but did not differed significantly from the placebo group [8].

Another small study delivering freshly harvested adipose-derived cells intracoronary in patients with STelevations myocardial infarction showed a trend towards improved LVEF [10].

Previously at our center, we have conducted studies using autologous bone marrow derived mesenchymal stromal cells for patients with chronic ischemic heart disease with and without heart failure [20-22]. These studies have demonstrated improvement in patients selfreported health, increase in LVEF, decreased left ventricular end-systolic volume and reduced amount of scar tissue.

It has been increasingly clear for many research groups, that the expansion of autologous cells in flasks makes it very difficult to deliver a standardized stem cell treatment. New cell culture methods using bioreactor systems to reach a standardized cell count for allogeneic treatments are now available for clinical use [23]. These systems have been used in a phase I trial, to produce an allogeneic cell product (CSCC_ASC) comparable to the one used in this trial as autologous product, for treatment in 10 patients with ischemic heart failure [24]. The aim was to investigate the safety of intra-myocardial injections of 100 million ASCs from healthy donors. No treatment-related side effects were observed.

Furthermore, CSCC_ASC is being tested in a Danish and European multicentre double-blinded placebocontrolled trial for treatment of patients with ischemic heart failure (EudraCT: 2015-001560-19 and EudraCT: 2015-002929-19, respectively) [25, 26].

Moreover, a single-centre study initiated January 2019 is investigating CSCC_ASC in patients 
with non-ischemic heart failure (EudraCT: 2018-002538-19).

In this study, the total amount of ASCs reached were injected into the patients allocated to the active therapy group, while the adipose tissue obtained from some of the patients in the placebo group, were used for characterization of ASCs [16]. Gene expression levels by quantitative real-time PCR analysis of ASCs showed that transcription of endothelial markers FOXF1, vWF, and VEGFR1 were up-regulated. By flow cytometry, we found the characteristic mesenchymal stem cell markers CD13, CD73, CD90, and CD105 on ASCs and they were lacking HLA-DR, CD19, and CD14.

So, the accumulated experience from clinical stem cell trials, the established safety and efficacy data has led this field to move from autologous to allogeneic therapy, reducing the logistical obstacles meet in previous studies. Furthermore, this field moves on to give a standardized amount of cell therapy safely and equally to all patients. However, as it is known from traditional pharmaceutical therapies, mostly repeated treatment is used. It may be of interest to investigate the role of cell therapy with two treatments within a short period.

The obvious benefit of cell therapy may be that it has the potential to regenerate the ischemic myocardium compared to conventional medical and interventional therapies. However, we did not have long term imaging modalities to detect changes in myocardial perfusion [27]. Moreover, in a selected group of patients the yield of cells and the effect of therapy may be higher [28]. Even though, this study is a randomized clinical trial, there were only male in the placebo group and a trend towards significant difference between the two groups for hypertension and previous coronary artery bypass grafting. Thus, these factors could potential be confounders.

Even though, the primary end-point did not differ between the two groups at 6 months follow-up, there was at 6 months follow-up a significant increase in bicycle exercise capacity in the ASC group, which was not the case for patients in the placebo group.

Probably, a larger amount of patients were needed in this study to detect a significant difference between groups for the primary end point. However, reduced cardiac symptoms are essential for the patient's quality of life, which was seen only for the patients in the ASC group in this long-term follow-up period.

\section{Conclusion}

In conclusion, patients receiving ASC injections, in this double-blinded placebo-controlled study, had preserved exercise capacity, while patients in the placebo group experienced significantly reduced exercise performance. Additionally, patients receiving ASCs had significantly improved cardiac symptoms, which was not the case for patients allocated in the placebo group.

\section{Abbreviations \\ ASC: adipose-derived stromal cell; CCS: Canadian Cardiovascular Society; CIHD: chronic ischemic heart disease; FBS: Fetal Bovine Serum; LVEF: left ventricular ejection fraction; METS: metabolic equivalents; MSC: mesenchymal stromal cell; NYHA: New York Heart Association; SD: standard deviation; VEGF: vascular endothelial growth factor.}

\section{Acknowledgements}

Not applicable.

\section{Authors' contributions}

$A Q, A B M, S H, E J, M H S$ and JK contributed to the study design and concept. $A Q, A B M$ and $A E$ analyzed and interpreted the data. SH, EJ and JK performed the treatments. Alla authors had a major contribution to the literature research and manuscript preparation. All authors read and approved the final manuscript.

\section{Funding}

This work has been supported by grants from Arvid Nilssons Foundation, Rigshospitalets Research Foundation, The Faculty of Health and Medical Science Research Foundation, and Aase and Ejnar Danielsens Foundation.

\section{Availability of data and materials}

The datasets used and/or analyzed during the current study are available from the corresponding author.

\section{Ethics approval and consent to participate}

The study protocol was approved by the Danish National Ethical Committee (02-268856) and Danish Medicines Agency (2612-2867), and complied with the Declaration of Helsinki. The study is registered in ClinicalTrials. gov (NCT01449032). The Good Clinical Practice Unit of the Capital Region, Denmark monitored the trial throughout the 3 years study period. All patients received oral and written information about the study and signed a written informed consent prior to inclusion.

\section{Consent for publication}

Not applicable.

\section{Competing interests}

The authors declare that they have no competing interests.

\section{Author details \\ ${ }^{1}$ Department of Cardiology \& Cardiac Catheterization Laboratory 2014, Rigshospitalet University of Copenhagen, Inge Lehmanns Vej 7, 2100 Copen- hagen, Denmark. ${ }^{2}$ Department of Cardiology, Gentofte University of Copen- hagen, Kildegårdsvej 28, 2900 Hellerup, Denmark. ${ }^{3}$ Cardiology Stem Cell Centre 9302, Rigshospitalet University of Copenhagen, Henrik Harpestrengsvej 4C, 2100 Copenhagen, Denmark.}

Received: 10 June 2019 Accepted: 26 October 2019

Published online: 12 November 2019

\section{References}

1. Ambrosy AP, Fonarow GC, Butler J, Chioncel O, Greene SJ, Vaduganathan $M$, et al. The global health and economic burden of 
hospitalizations for heart failure: lessons learned from hospitalized heart failure registries. J Am Coll Cardiol. 2014;63:1123-33.

2. Moran AE, Forouzanfar MH, Roth GA, Mensah GA, Ezzati M, Flaxman A, et al. The global burden of ischemic heart disease in 1990 and 2010: the Global Burden of Disease 2010 study. Circulation. 2014;129:1493-501.

3. Strem BM, Hicok KC, Zhu M, Wulur I, Alfonso Z, Schreiber RE, et al. Multipotential differentiation of adipose tissue-derived stem cells. Keio J Med. 2005;54:132-41

4. Bochev I, Elmadjian G, Kyurkchiev D, Tzvetanov L, Altankova I, Tivchev $P$, et al. Mesenchymal stem cells from human bone marrow or adipose tissue differently modulate mitogen-stimulated B-cell immunoglobulin production in vitro. Cell Biol Int. 2008;32:384-93.

5. Fraser JK, Schreiber R, Strem B, Zhu M, Alfonso Z, Wulur I, et al. Plasticity of human adipose stem cells toward endothelial cells and cardiomyocytes. Nat Clin Pract Cardiovasc Med. 2006;3(Suppl 1):S33-7.

6. Heydarkhan-Hagvall S, Schenke-Layland K, Yang JQ, Heydarkhan S, Xu Y, Zuk PA, et al. Human adipose stem cells: a potential cell source for cardiovascular tissue engineering. Cells Tissues Organs (Print). 2008;187:263-74.

7. Helder MN, Knippenberg M, Klein-Nulend J, Wuisman PIJM. Stem cells from adipose tissue allow challenging new concepts for regenerative medicine. Tissue Eng. 2007;13:1799-808.

8. Henry TD, Pepine CJ, Lambert CR, Traverse JH, Schatz R, Costa M, et al. The Athena trials: autologous adipose-derived regenerative cells for refractory chronic myocardial ischemia with left ventricular dysfunction. Catheter Cardiovasc Interv. 2017;89:169-77.

9. Perin EC, Sanz-Ruiz R, Sánchez PL, Lasso J, Pérez-Cano R, Alonso-Farto $J C$, et al. Adipose-derived regenerative cells in patients with ischemic cardiomyopathy: the PRECISE Trial. Am Heart J. 2014;168(88-95):e2.

10. Houtgraaf JH, den Dekker WK, van Dalen BM, Springeling T, de Jong R, van Geuns RJ, et al. First experience in humans using adipose tissuederived regenerative cells in the treatment of patients with ST-segment elevation myocardial infarction. J Am Coll Cardiol. 2012;59:539-40.

11. Sadat $\mathrm{S}$, Gehmert $\mathrm{S}$, Song $\mathrm{Y}-\mathrm{H}$, Yen Y, Bai X, Gaiser S, et al. The cardioprotective effect of mesenchymal stem cells is mediated by IGF-I and VEGF. Biochem Biophys Res Commun. 2007;363:674-9.

12. Gehmert S, Sadat S, Song Y-H, Yan Y, Alt E. The anti-apoptotic effect of IGF-1 on tissue resident stem cells is mediated via PI3-kinase dependent secreted frizzled related protein 2 (Sfrp2) release. Biochem Biophys Res Commun. 2008;371:752-5.

13. Alt E, Pinkernell K, Scharlau M, Coleman M, Fotuhi P, Nabzdyk C, et al. Effect of freshly isolated autologous tissue resident stromal cells on cardiac function and perfusion following acute myocardial infarction. Int J Cardiol. 2010;144:26-35.

14. Qayyum AA, Haack-Sørensen M, Mathiasen AB, Jørgensen E, Ekblond A, Kastrup J. Adipose-derived mesenchymal stromal cells for chronic myocardial ischemia (MyStromalCell Trial): study design. Regen Med. 2012;7:421-8.

15. Qayyum AA, Mathiasen AB, Mygind ND, Kühl JT, Jørgensen E, Helqvist $S$, et al. Adipose-derived stromal cells for treatment of patients with chronic ischemic heart disease (MyStromalCell Trial): a randomized placebocontrolled study. Stem Cells Int. 2017;2017:5237063.

16. Follin B, Tratwal J, Haack-Sørensen M, Elberg JJ, Kastrup J, Ekblond A. Identical effects of VEGF and serum-deprivation on phenotype and function of adipose-derived stromal cells from healthy donors and patients with ischemic heart disease. J Transl Med. 2013;11:219.

17. Losordo DW, Schatz RA, White CJ, Udelson JE, Veereshwarayya V, Durgin $\mathrm{M}$, et al. Intramyocardial transplantation of autologous CD34+ stem cells for intractable angina: a phase I/lla double-blind, randomized controlled trial. Circulation. 2007;1 15:3165-72.

18. Povsic TJ, Henry TD, Traverse JH, Fortuin FD, Schaer GL, Kereiakes DJ, et al. The RENEW trial: efficacy and safety of intramyocardial autologous CD34(+) cell administration in patients with refractory angina. JACC Cardiovasc Interv. 2016;9:1576-85.

19. Losordo DW, Henry TD, Davidson C, Sup Lee J, Costa MA, Bass T, et al. Intramyocardial, autologous CD34+ cell therapy for refractory angina. Circ Res. 2011;109:428-36.

20. Friis T, Haack-Sørensen M, Mathiasen AB, Ripa RS, Kristoffersen US, Jørgensen $\mathrm{E}$, et al. Mesenchymal stromal cell derived endothelial progenitor treatment in patients with refractory angina. Scand Cardiovasc J. 2011:45:161-8.

21. Mathiasen AB, Haack-Sørensen M, Jørgensen E, Kastrup J. Autotransplantation of mesenchymal stromal cells from bone-marrow to heart in patients with severe stable coronary artery disease and refractory angina-final 3-year follow-up. Int J Cardiol. 2013;170:246-51.

22. Mathiasen $A B$, Qayyum AA, Jørgensen E, Helqvist S, Fischer-Nielsen A, Kofoed KF, et al. Bone marrow-derived mesenchymal stromal cell treatment in patients with severe ischaemic heart failure: a randomized placebo-controlled trial (MSC-HF trial). Eur Heart J. 2015;36:1744-53.

23. Haack-Sørensen M, Follin B, Juhl M, Brorsen SK, Søndergaard RH, Kastrup $J$, et al. Culture expansion of adipose derived stromal cells. A closed automated Quantum Cell Expansion System compared with manual flask-based culture. J Transl Med. 2016;14:319.

24. Kastrup J, Haack-Sørensen M, Juhl M, Harary Søndergaard R, Follin B, Drozd Lund $L$, et al. Cryopreserved off-the-shelf allogeneic adiposederived stromal cells for therapy in patients with ischemic heart disease and heart failure—a safety Study. Stem Cells Transl Med. 2017;6:1963-71.

25. Kastrup J, Schou M, Gustafsson I, Nielsen OW, Møgelvang R, Kofoed KF, et al. Rationale and design of the first double-blind, placebo-controlled trial with allogeneic adipose tissue-derived stromal cell therapy in patients with ischemic heart failure: a Phase II Danish multicentre study. Stem Cells Int. 2017;2017:8506370.

26. Paitazoglou C, Bergmann MW, Vrtovec B, Chamuleau SAJ, van Klarenbosch B, Wojakowski W, et al. Rationale and design of the European multicentre study on stem cell therapy in IschEmic non-treatable Cardiac diseasE (SCIENCE). Eur J Heart Fail. 2019;21:1032-41.

27. Qayyum AA, Kastrup J. Measuring myocardial perfusion: the role of PET, MRI and CT. Clin Radiol. 2015;70:576-84.

28. Qayyum AA, Kaur KP, Mathiasen AB, Haack-Sørensen M, Ekblond A, Kastrup J. Influence of patient related factors on number of mesenchymal stromal cells reached after in vitro culture expansion for clinical treatment. Scand J Clin Lab Invest. 2017;77:541-8.

\section{Publisher's Note}

Springer Nature remains neutral with regard to jurisdictional claims in published maps and institutional affiliations.
Ready to submit your research? Choose BMC and benefit from:

- fast, convenient online submission

- thorough peer review by experienced researchers in your field

- rapid publication on acceptance

- support for research data, including large and complex data types

- gold Open Access which fosters wider collaboration and increased citations

- maximum visibility for your research: over $100 \mathrm{M}$ website views per year

At BMC, research is always in progress.

Learn more biomedcentral.com/submissions 